\title{
PENDIDIKAN BISNIS, BISNIS PENDIDIKAN
}

\author{
Bagus Sumargo 1
}

\begin{abstract}
The implication of educations decentralization implies that colleges have authority to manage the whole education process. Nevertheless, the education have to be conducted professionally. The colleges should determine one study program having business oriented. Therefore, the education is driven into business purposes.
\end{abstract}

Keywords: education, education managements, business

ABSTRAK
Implikasi desentralisasi pendidikan adalah perguruan tinggi memiliki kewenangan mengatur pendidikan sepenuhnya. Namun, pendidikan tetap harus mengutamakan profesionalisme. Perguruan tinggi menentukan program pendidikan yang berorientasi bisnis. Pada akhirnya, pendidikan dijadikan sebagai bisnis.

Kata kunci: pendidikan, manajemen pendidikan, bisnis

\footnotetext{
${ }^{1}$ Staf Peneliti BPS, Jakarta \& Staf Pengajar FMIPA, UBiNus, Jakarta
} 


\section{PENDAHULUAN}

Kesulitan dalam mewujudkan fungsi dan peranan Perguruan Tinggi (PT) hanya dapat diatasi dengan tiga paradigma, yaitu kemandirian, akuntabilitas, dan jaminan kualitas yang lebih besar, demikian ungkap Rektor Institut Agama Islam Negeri (IAIN) Jakarta, Prof. Dr. Azyumardi Azra, M.A., dalam seminar nasional bertajuk "Pengembangan Program Pascasarjana IAIN di Indonesia: In Memoriam Prof. Dr. Harun Nasution (1919-1998), Jakarta 18 September 2000”. Paradigma kemandirian menitikberatkan pada otonomi seluas-luasnya. Paradigma kedua lebih mengacu pada pemanfaatan sumber keuangan (akuntabilitas) secara lebih bertanggungjawab. Paradigma ketiga membutuhkan evaluasi internal secara terus menerus dan berkesinambungan, di samping evaluasi eksternal yang saat ini dilakukan oleh Badan Akreditasi Nasional (BAN) dan untuk tingkat dunia adalah ISO. Ketiga paradigma itu harus saling berkaitan, bahkan bersifat interdependensi dan ketiganya harus diaktualisasikan secara simultan.

Tantangan untuk ketiga paradigma tersebut, lebih berat dijalani oleh Perguruan Tinggi Swasta (PTS). Terutama saat ini, pemerintah menentukan kebijakan Desentralisasi Pendidikan sehingga tuntutan yang paling mendasar adalah penyiapan Sumber Daya Manusia (SDM) yang siap pakai dan berkemampuan "global". Salah satu lembaga pendidikan yang mempunyai peran dan tanggung jawab yang besar adalah PTS. Dengan kata lain, PTS harus memiliki kiat dan strategi dalam pengelolaan pendidikan secara profesional sehingga PTS dapat menjalankan ketiga paradigma yang dimaksud.

Di negara Indonesia, "budaya” masyarakat masih menjunjung tinggi Perguruan Tinggi (PT). Contoh, seorang ibu yang telah ditinggalkan suaminya untuk selamanya bekerja menjual gorengan pisang dan melarang anaknya membantu usaha dagangannya. Ibu tersebut berjuang demi cita-cita mempunyai seorang anak sarjana. Contoh lain, pada suatu Departemen, si A (lulusan SMU) yang mempunyai kinerja sangat memuaskan, tetap menjadi seorang staf sampai pensiun sedangkan si B yang bergelar Dr. (konon gelar tersebut didapat dengan cara membeli dari sebuah universitas tidak terkenal di dalam negeri) mempunyai kedudukan yang baik daripada si A.

Jika dicermati maka pendidikan merupakan bisnis yang menguntungkan untuk dijalani sebagai ladang usaha. Akan tetapi, bagi pengusaha dalam bidang pendidikan, juga harus hati-hati dalam memfokuskan jenis pendidikan yang paling menguntungkan dan berprospek untuk dikembangkan. Tidak jarang lembaga pendidikan yang dijalani hanya berumur pendek karena bidang studi yang ditawarkan relatif sedikit peminatnya (mahasiswa). 


\section{PEMBAHASAN}

\section{Desentralisasi Pendidikan}

Desentralisasi pendidikan yang dijalankan seiring dengan pelaksanaan otonomi daerah merupakan bagian dari upaya memindahkan titik berat pendidikan nasional yang semula sentralistis menjadi berbasis pada masyarakat. Di era otonomi, pendidikan harus tumbuh dari masyarakat dan ditumbuhkan sendiri oleh kekuatan masyarakat. Pengelolaan pendidikan dalam kerangka otonomi daerah merupakan upaya untuk meningkatkan efisiensi dan efektifitas dalam mengimplementasikan kebijakan dan perencanaan program pendidikan. Satu yang paling penting adalah mengenai kewenangan penuh, yaitu bila kewenangan daerah yang masih setengah-setengah (artinya pusat masih memberikan pedoman kebijakan pendidikan kepada daerah) maka akan sia-sialah segala sesuatu yang akan dipersiapkannya.

Keadaan itu memaksakan perlu adanya ahli pendidikan yang dapat berpikir mengenai landasan filosofis, proses pelaksanaan, mutu, organisasi, dan pengembangan pendidikan. Selain itu, juga tenaga manajer pendidikan berkualitas yang selanjutnya distratakan dalam suatu unit lembaga pendidikan yang mempunyai komitmen memanusiakan manusia dan selalu berorientasi ke depan dan mempunyai manajemen mutu yang dapat dibanggakan. Salah satu bentuk lembaga pendidikan yang dimaksud adalah PTS. Ada baiknya desentralisasi pendidikan lebih memberikan kewenangan pada otonomi sekolah sehingga PTS lebih leluasa dan bebas dan bertanggung jawab dalam mengemban misi dan visi PTS tersebut. Hubungan PTS dengan desentralisasi pendidikan adalah PTS harus mampu membaca peta Sumber Daya Alam (SDA), kemampuan daerah, dan urgensinya akan kebutuhan SDM yang dapat membangun daerahnya secara efisien dan efektif.

\section{Pendidikan "Bisnis”}

Anggaran pendidikan merupakan kendala yang paling utama dalam mempengaruhi berhasil tidaknya misi dan visi suatu PTS. Idealnya, secara nasional kebutuhan besaran anggaran pendidikan adalah sebesar 25 persen dari Anggaran Pendapatan dan Belanja Negara (APBN). Akan tetapi, karena kondisi pemerintah sekarang yang tidak menentu, baik masalah ekonomi maupun politik, maka anggaran pendidikan relatif kecil, yaitu berkisar 5-6 persen dari APBN. Hal itu menuntut PTS harus mempunyai kiat tersendiri agar mereka dapat menjalankan komitmennya dalam bidang pendidikan dengan langgeng dan tetap dapat menghasilkan SDM Indonesia yang berkualitas. PTS harus mampu mencari sendiri sumber keuangan atau memaksa PTS mengelola pendidikan yang bernuansa "bisnis". Maksud bernuansa "bisnis" disini adalah bidang studi yang banyak peminatnya, yaitu bidang studi yang dibutuhkan oleh pasar kerja atau mempunyai pretise tersendiri bagi lulusannya atau mempunyai harga jual yang tinggi (biasanya pekerja berdasi yang kuliah melalui jalur ekskutif program pascasarjana). 
Secara lisan, terlihat identitas kualitas bidang studi (yang diperbincangkan oleh masyarakat) pada suatu PT, yaitu popularitas suatu bidang studi, misalnya Uiversitas Indonesia terkenal dengan lulusan dari bidang studi “Ekonomi dan Kedokteran”, Institut Pertanian Bogor dengan lulusan bidang studi "Pertanian”, dan demikian juga untuk masing-masing PT lainnya. Unggulan bidang studi bagi suatu PTS penting artinya sebagai pretise PTS itu sendiri dan merupakan produk atau komoditi unggulan yang bernuansa "bisnis" dengan tidak mengesampingkan mutu.

Umumnya, peminat pendidikan (mahasiswa) cenderung memilih bidang studi tertentu yang dapat memberikan pengharapan untuk menjadikan peluang "kaya". Artinya, bidang studi tersebut nantinya akan mempermudah mendapat pekerjaan dalam pasar kerja, bidang studi itu menjanjikan penghasilan yang tinggi. Implikasinya adalah suatu bidang studi yang banyak peminatnya mempunyai nilai "bisnis". Secara sederhana, dapat diterangkan dengan silogisma, yaitu semakin banyak mahasiswa di suatu bidang studi maka akan memberikan dampak keuntungan bagi pengelola pendidikan. Oleh karena itu, pengelola pendidikan dengan kondisi keuangan yang baik (diperoleh dari pungutan pendidikan dari mahasiswa) akan lebih tenang dalam mengemban misi dan visi pendidikan, khususnya dalam menghadapi era informasi. Contoh, bidang studi yang bernuansa bisnis adalah Agrobisnis, Teknik Informatika/Industri, Akuntansi, dan Manajemen. Akan tetapi, hal itu harus disesuaikan dengan kondisi di suatu wilayah. Misalnya, di Bali, wacana bidang studi yang bernuansa bisnis adalah bahasa asing dan pariwisata. Pada akhirnya, dapat saja bidang studi yang benuansa bisnis tersebut dijadikan ciri atau mencirikan potensi PTS tertentu.

\section{Pendikan Bisnis, Bisnis Pendidikan}

Menurut Hermawan K. (Leading Service Officer, MarkPlus \& Co), kata "bisnis" yang diletakkan pada kata "pendidikan", memungkinkan untuk memiliki arti negatif, yaitu mendapatkan keuntungan sebesar-besarnya dengan meninggalkan mutu atau kualitas. Kalau sudah begini jadinya, dapat jadi orang akan menilai bisnis sebagai dirtyword. Padahal, sebenarnya suatu bisnis yang dijalankan dengan baik haruslan menghasilkan suatu kualitas. Bahkan, dalam bisnis nonpendidikan pun, kualitas produk jasa harus dapat dipertanggungjawabkan. Menurutnya, ada lima tingkatan "bisnis pendidikan”, yaitu Transformation-Business, Product-Business, Service Business, Experience-Business, dan Commodity-Business.

Harapan untuk bisnis pendidikan dapat berada di tingkat yang paling tinggi, yaitu bisnis transformasi sehingga harus benar-benar ada value yang terasa oleh peserta pendidikan (konsumen). Kalau suatu program pendidikan dibuat tanpa kualitas sama sekali dan ijazahnya dijual murah maka bisnis pendidikan itu akan jatuh ke level paling bawah, yaitu Commodity-Business. Pendidikan akan menjadi Product-Business, kalau programnya distandardisasikan tanpa melihat kebutuhan mahasiswa. Apabila ada jasa yang memperhatikan kebutuhan mahasiswa, termasuk banyaknya pilihan kelas yang dapat dipilih maka bisnis pendidikan itu sudah naik ke tingkat Service-Business. Artinya, 
pendidikan itu bukan produk yang kaku lagi. Akan tetapi, sudah cukup luwes dan fleksibel sebagaimana layaknya karakteristik suatu industri jasa. Jika pendidikan sudah disampaikan dalam suatu situasi yang lebih dekat dengan praktik sehari-hari maka pendidikan dapat jadi suatu experience. Caranya dapat bermacam-macam, termasuk pendidikan studi kasus, kerja lapangan, guest lecture dan sebagainya.

Skema kunci untuk menggambarkan pendidikan bisnis sebagai bisnis pendidikan adalah adanya keterkaitan yang sangat erat antara program pendidikan yang benuansa "bisnis" dengan kualitas. Akan tetapi, sekali lagi yang perlu diingatkan adalah pentingnya penopang untuk menjalankan itu semua, yaitu "Biaya”. Oleh karena itu, pengelola suatu PTS harus berusaha mencari peluang pengelolaan bisnis pendidikan yang lain, seperti wacana berikut ini.

1. PTS dengan suatu basis bidang studi (menjadi ciri PTS tersebut) untuk selalu mengupayakan melakukan kerja sama bisnis dengan PT lain yang memang telah mapan di bidang studi tersebut, yaitu sebagai Strategic Business Unit (Daughter Institutions) atau kegiatan Partner Institutions yaitu semacam Franchising.

2. Menerapkan strategi pemasaran yang jitu, yaitu mengupayakan menangkap "pasar: kalangan tertentu”. Misalnya, peserta pendidikan adalah warga negara keturunan (asing) dan pendapatan orang tua mahasiswa menengah ke atas.

3. Menyediakan program pendidikan khusus yang sangat diperlukan oleh pelaku "bisnis". Seperti, pelatihan manajemen proyek, pelatihan komputer, sekretaris, bahasa, dan sejenisnya.

4. Menyelenggarakan "Dual-Gelar" yang penyelenggaraannya bekerja sama dengan PT luar negeri.

\section{PENUTUP}

Beberapa simpulan yang dapat diungkapkan sebagai berikut.

1. Untuk kelanggengan dan eksisnya dalam pengelolaan program pendidikan, PTS tidak terlepas dari motto: "Pendidikan itu adalah Bisnis dengan tidak mengesampingkan mutu”.

2. ISO penting untuk suatu PTS, sebagai jaminan mutu program pendidikan suatu PTS.

3. Sebaiknya, penentuan suatu program pendidikan mengarah pada kebutuhan pasar yang berorientasi masa depan. 


\section{DAFTAR PUSTAKA}

Hermawan K. 2000. “Transformasi Pendidikan.” Kompas. 20 Agustus 2000. Jakarta.

Kismono, G. 2001. Bisnis Pengantar. Yogyakarta: BPFE.

Wibisono, D. 2000. Riset Bisnis. Yogyakarta: BPFE.

William, C. 2001. Manajemen. Jakarta: Penerbit Salemba Empat. 